\title{
Nature tourism trends in Australia with reference to the Greater Blue
}

\section{Mountains World Heritage Area}

Nigel Hardiman ${ }^{\mathrm{a}, \mathrm{b}}$ and Shelley Burgin ${ }^{\mathrm{c}, \mathrm{d}^{*}}$

aSydney City School of Business, Top Education Institution, Eveleigh, Australia, 2015

${ }^{\mathrm{b} C}$ Current address: Lincoln International Business School, University of Lincoln, Brayford Pool, Lincoln LN6 7TS, United Kingdom

${ }^{\mathrm{c}}$ Faculty of Science and Health, Western Sydney University, Locked Bag 1797, Penrith, Australia, 2751

${ }^{\mathrm{d} C}$ Current address: Faculty of Society and Design, Bond University, Gold Coast, Australia, 4229

Corresponding author:

Emeritus Professor Shelley Burgin,

Faculty of Society and Design,

Bond University,

Gold Coast, Australia, 4229.

Phone: +61 755951474

Fax: $\quad+61755951474$

Email: sburgin@bond.edu.au

\begin{abstract}
Nature-based tourism has been viewed as a large and growing segment of the tourism market. Advocates of nature-based tourism argue its potential to generate income for biodiversity conservation and local economic benefit, while detractors fear a risk of 'loving our parks to death'. Some recent studies have suggested that nature-based tourism may be declining on a per capita basis, especially in economically developed countries. Others have detected no such trend. Nature-based tourism is a key industry within Australia, based strongly on its unique scenery and biodiversity. We compared nature-based visitation and population growth during 1998-2012 for Australia overall and specifically for the Greater Blue Mountains World Heritage Area which is adjacent to the country’s
\end{abstract}


largest conurbation of Greater Sydney. We found substantial declines in domestic per-capita visitation, both nationally and regionally. Because visitation provides the 'political capital' for parks to survive, strategies to encourage visitation should be a target for land managers. Since children foster environmentally responsible behaviour in adults, they should be part of the focus for developing diverse experiences that encourage park visitation.

Keywords: destination planning, protected area management, tourism trends, national park visitation, ecotourism

\section{Introduction}

Despite a paucity of quantifiable and comparable data, nature-based tourism has frequently been reported to be a large and growing segment within the global tourism market (Balmford, 2009; Bell, Tyrväinen, Sievänen, Pröbstl, and Simpson, 2007; Buckley, 2003; Nyaupane, Morais, and Graefe, 2004), capable of generating substantial income for both biodiversity conservation and economic development in local regions (Gössling, 1999; Kruger, 2005; Naidoo and Adamowicz, 2005; Wilkie and Carpenter, 1999). Such attributes are important for two reasons: firstly, decisions to protect natural areas are increasingly being assessed on their ability to provide economic benefit (Bushell and Eagles, 2007; Naidoo, Balmford, Ferraro, Polasky, Ricketts, and Rouge, 2006; Naughton-Treves, Holland, and Brandonet, 2005) and secondly, direct experience of the natural environment, especially as children, has been argued to be important in fostering environmentally responsible behaviour and support for conservation as adults (e.g., Chawla, 1998; Wells and Lekies, 2006; Zaradic and Pergams, 2007). However, debate has been generated by a widely-publicised study by Zaradic and Pergams (2007) that showed that, expressed on a per capita basis, visits to protected areas in the United States of America (U.S.) (State Parks, National Parks and National Forests) and Japan (National Parks) have been in decline since the late 1980 s, reducing typically by $1.0 \%$ to $1.3 \%$ annually. In 2008, Pergams and Zaradic reported that the total decline was between $18.0 \%$ and 
25.0\%. Declines in per capita visitation to U.S. national parks have also been reported in other studies (e.g., Balmford et al., 2009; Warnick, Stevens, Schuett, Kuentzel, and More, 2009). Absolute visitation numbers to these areas was found to be largely static despite a growing national population. If numbers decline and fewer people are visiting natural areas and/or visiting them less frequently, there are serious socio-economic outcomes for local communities when income and typically employment declines (Shaw and Williams, 1997; Kareithi, 2003; Silori, 2003), and for nature conservation because where tourism has a high perceived direct value it may support its longer term protection for nature conservation (Gössling, 1999; Kiss, 2004).

It remains unclear, however, whether the abovementioned declines in the U.S. and Japan reflect universal trends or are specific to those countries. In their 2008 paper, Pergams and Zaradic reported that they found no discernible trend in per capita visitation to Spanish national parks during 19962006. Balmford et al. (2009), in a study of 280 terrestrial protected areas in 20 countries, found marked geographical variation in visitation trends among countries. Their results showed that total visits to the protected areas sampled grew on average in 15 out of 20 countries, declined in four and remained stable in one, while per capita visitation rose in 14 countries and fell in six. The question of how nature tourism is developing globally, and among individual countries, therefore remains unclear. Australia is the world's eighth largest tourism market in terms of expenditure (UNWTO, 2012) and tourism is a key industry within the country, directly and indirectly employing around 907,100 people (7.9\%) and contributing, for example, AUD\$73.3 billion (5.2\%) in Gross Domestic Product in 2010-2011 (TRA, 2012). Based on the combination of warm climate, scenic beauty and unique wildlife, nature has traditionally been the core of Australia's domestic and international tourism product, evidenced by its 16 United Nations Educational, Scientific and Cultural Organization World Heritage Areas listed for natural or mix of natural and cultural values, the most of any country (Tisdell, 2010; UNESCO, 1992-2011). Trends in nature tourism in Australia in recent years may, therefore, provide insights into long-term trends in nature tourism, and may be of some benefit as a basis of investigation for countries of comparable economic development. Here we 
present and discuss changes in nature tourism for Australia nationally, and the Greater Blue

Mountains World Heritage Area (GBMWHA) specifically for the 15 years between 1998 and 2012, using data from Tourism Research Australia’s National Visitor Survey (NVS; TRA, 2015a) and International Visitor Survey (IVS; TRA, 2015b), the country’s most comprehensive surveys of tourist activity. We used these data rather than more direct gate entry counts because most protected areas in Australia, including the GBMWHA, have 'free open access' and thus direct visitor counts are not available.

\section{Greater Blue Mountains World Heritage Area}

We chose to focus our study on the Blue Mountains Tourism Region (cf. GBMWHA) because of its historical popularity as a tourist destination (Hardiman and Burgin, 2013), its proximity to Australia's largest city, Sydney, and because its major attraction has always been its natural beauty (Hardiman and Burgin, 2010a). The Blue Mountains form a segment of the Great Dividing Range on the eastern seaboard of Australia (Hardiman and Burgin, 2010a). Since completion of the trans-mountain railway in the 1860s, the region has attracted domestic and international visitors with its scenery, wildlife and climate, and is a well-known nature tourism icon within the country. In November 2000, the protection of the area was further enhanced when around 1,070,000 hectares, encompassing seven contiguous national parks and one conservation reserve were listed as the Greater Blue Mountains World Heritage Area (GBMWHA; DECC, 2009).

Tourism Research Australia (TRA, 2015b) defines, and reports against, the Blue Mountains Tourist Region. This Region effectively encompasses the tourism activity in the GBMWHA. It abuts the Hunter Tourism Region in the North, Central New South Wales to its West, the Australian Capital Territory in the South, and on the Eastern edge, the Greater Sydney conurbation (i.e., Sydney Tourism Research Region). The city’s Central Business District is only 50 km away on the coastal side of the Range. In 2013-2014, the population of Greater Sydney represented 20.4\% of the total Australian population, placing more than one in every five Australians within a one-hour train or car 
journey from a nature-based World Heritage Area (ABS, 2015). Sydney also serves as the major gateway for international visitor arrivals into Australia (Baum, 1997; Short et al., 2000).

\section{Methods}

The data relevant to this paper were drawn from the estimates of visitation collected by Tourism Research Australia for domestic and international visitor profiles nationally for the whole of Australia, and specifically for the ‘Blue Mountains Region’ for the 15 years between 1998 and 2012 (TRA, 2013). This period was chosen because it is the longest recent time series available that had validity (see TRA, 2015a), and the focus of the study was on 'nature trips'.

\section{Definition of 'trips'}

Definitions used by Tourism Research Australia are based on those provided by the United Nations World Tourism Organization while Tourism Research Australia interviews are conducted with people who had travelled for purposes that include holiday, visiting friends and relatives, business, education, and employment. As opposed to the International Visitor Survey (IVS) which is restricted to the most recent nature trip made, the National Visitor Survey (NVS) data for domestic daytrips and overnight trips is based on 'all trips' made during the recall period (i.e., multiple trips may be recorded), and not simply unique visits/persons of the IVS (Godfrey, pers. comm.; TRA, 2013).

Within the context of this paper we were interested in nature trips since 'nature' is the major attraction for visitors to the Blue Mountains Region. 'Nature trip' is defined in the NVS and IVS data as involving at least one of the following activities - visit to national/state parks, wildlife parks, zoos, aquaria, botanical or other public gardens, bushwalking or rainforest walks, whale/dolphin watching, and snorkelling or scuba diving (TRA, 2009). For our analysis, we extracted the number of nature trips reported in the NVS - domestic overnight and day nature trips for [i] the Blue Mountains Tourist Region, and [ii] Australia overall, and the IVS for Australia overall. Because IVS data does not report 
'nature trips' by Region we used the more generic number of trips made for 'holiday or pleasure' to the Blue Mountains Tourist Region reported in the IVS (TRA, 2015b).

\section{International Visitor Survey Methodology}

The IVS records the number of international visitors to the Blue Mountains Tourism Region. While the IVS does not report on the number of 'nature trips' by region (TRA, 2015b), the Blue Mountains has a strong focus on nature tourism with no other major draw for international tourists. This is evidenced by, for example, the ‘Management Vision’ in the Strategic Plan for the Region which claims '... the outstanding natural and cultural values and integrity of the Greater Blue Mountains World Heritage Area are identified, protected, and conserved and presented in an ecologically sustainable and culturally appropriate manner'. Such management is carried out by the National Parks and Wildlife Service (New South Wales) with additional resources from the Federal Department of the Environment, Water, Heritage and the Arts (DECC, 2009, p. 1). This management focus, and advertising of tourism in the Blue Mountains (e.g., Australia.com, 2016; Destination NSW, 2016; SWRN, 2016), clearly demonstrates that the core business of the Region is nature tourism. While assuming all international trips are nature trips may be an over-estimation, based on the focus of management and advertising in the Region such error would likely to be minimal. In the absence of more precise data, it was assumed that the IVS data were fit for purpose.

Prior to January 2004, 20,000 short term international visitors departing Australia, aged 15 years and over were surveyed annually. Subsequently, the number of interviews was increased to 40,000 annually. Interviews are conducted in the departure lounges of the eight major international airports of Australia (Sydney, Melbourne, Brisbane, Cairns, Perth, Adelaide, Darwin, and Gold Coast) by Computer Assisted Personal Interviewing in four languages (English, Japanese, Mandarin, Korean). The total number of interviews conducted with residents of specific countries and regions is distributed among airports. Target samples are achieved by selecting monthly samples of departing flights carrying visitors within the various categories sought (TRA, 2015b). 
Survey results are weighted to data on international visitor numbers over the period, sourced from the Department of Immigration and Citizenship, in addition to data from the Australian Bureau of Statistics. Weighting variables include country of residence, State of arrival, and main purpose of journey (TRA, 2015b). In contrast to the NVS (which reports total number of multiple trips made), IVS report the unique number of visitors/persons, and only data on activities of the 'most recent trip' made by the visitor are recorded (Godfrey, pers. comm.; TRA, 2015b).

\section{National Visitor Survey Methodology}

The NVS was introduced in January 1998 to replace the previous Domestic Tourism Monitor (DTM) survey. Aspects of sampling and collection methodologies used and actual questions asked of respondents in these two methodologies differ. Comparison of results between the two databases is therefore invalid (TRA, 2015a). Between January 1998 and January 2005, NVS interviews of 80,000 Australian residents aged 15 years and over, were undertaken annually. From 2005 the sampling base was increased to 120,000 interviews annually. This increased sample size was implemented to enhance the validity of estimates for smaller states/territories, and at a regional level (e.g., Blue Mountains Tourist Region; TRA, 2015a). To be representative of the Australian population, respondents to the NVS are randomly sampled based on place of residence, age, and sex. Individuals are interviewed in their homes via fixed line telephones using random digit dialling, and a Computer Assisted Telephone Interviewing system (TRA, 2015a). For this paper, data for all 'nature trips' made and reported during the sampling period were extracted from the NVS.

\section{Variability in National Visitation Survey and International Visitor Survey sample data}

Both the NVS and IVS are sample-based estimates of visitation, rather than censi of actual visitation. The results are, therefore, subject to variability and sample error typical of such data collection. Tourism Research Australia publishes standard error rates for different data estimate ranges for both surveys. These standard errors are calculated at the 95\% confidence interval for the estimated figures. 
The same error rates apply to both Australian and Regional data, and to visitor/trip data (Godfrey, pers. comm.; TRA, 2014). To minimise errors, we report on the highest error rate for the range in which a TRA estimate fell (see Table 1).

We report on data collected by the NVS and IVS between 1998 and 2012, from individuals 15 years and over. The reason for commencing the study with 1998 data is that the NVS was introduced in that year, and the IVS in 1999 (TRA, 2015a, b). In 2013 there was a change in methodology. At that time, surveys moved from fixed-only telephones interviews, to incorporate mobile telephones (TRA, 2015c). This latter date also coincided with the Australian Bureau of Statistics revising the estimated Australian resident population (used as an input to NVS weighting; TRA, 2015c). The period 1998-2012 therefore represents a continuous period of data collection using essentially comparable methodologies, and the period also spans the period pre- and post-World Heritage listing of the Blue Mountains in 2000 (Hardiman and Burgin, 2013).

\section{Results}

International visitors constituted only a small minority $(<10 \%)$ of the total number of nature trips undertaken in the Blue Mountains and Australia overall. The estimated number of such trips made to the Blue Mountains by international visitors during the study period showed a mean annual decline of $-0.2 \%$ (Table 2). Although the number of nature trips made in Australia overall by international visitors increased slightly by a mean annual growth of $+2.0 \%$ over the period (Table 3 ), the market share of nature trips fell by an annual average of $-0.6 \%$ over the period under analysis (Table 3 ).

Domestic visitors are responsible for the overwhelming majority of nature visits in both the Blue Mountains and Australia overall, and trends in behaviour in this group are therefore potentially most important. During the study period, the population of Greater Sydney increased by an annual average of $1.2 \%$ with a total increase of $15.1 \%$ from 3.97 million to 4.67 million. Despite this growth, the estimated number of nature trips to the Blue Mountains made by domestic visitors declined, on average, by $-2.2 \%$ per annum over the study period. Trip numbers declined significantly 
(non-overlapping standard errors) by 50.3\% from a peak in 1998 to 2002, and despite a general trend of recovery in subsequent years, the number of trips was still 36.7\% below 1998 levels in 2012 (Table 2). The decline in number of day nature trips by domestic visitors to the Blue Mountains was even more marked on a per capita basis, falling on average by $-3.5 \%$ annually over the study period. Trips per capita declined by 54.5\% from a peak in 1998 to 2002 and, despite a general trend of recovery in subsequent years were still 48.5\% below 1998 levels in 2012 (Table 2).

The estimated number of overnight nature trips to the Blue Mountains by domestic visitors also declined, on average, by $-1.7 \%$ over the study period. Trips declined significantly (nonoverlapping standard errors) by $29.2 \%$ from a peak in 1998 to 2004 . While there was some recovery and general stability post-2005, trip numbers were still 35.6\% below 1998 levels in 2012 (Table 2).

The decline in number of overnight nature trips by domestic visitors to the Blue Mountains was even more marked on a per capita basis, falling on average by $-2.7 \%$ annually over the study period. Trips per capita declined by 61.5\% from a peak in 1998 to 2004, remained generally stable in subsequent years and were still 46.2\% below 1998 levels in 2012 (Table 2).

During the study period, the population of Australia increased by an annual average of $+1.4 \%$ and there was a total increase of $21.4 \%$ from 18.7 million to 22.7 million people. Despite such growth, the estimated number of day nature trips made in Australia overall by domestic visitors remained generally stable over the study period, with a low mean annual change of $+0.6 \%$. Although trips declined significantly (non-overlapping standard errors) by 30.7\% from a peak in 1999 to 2001, levels recovered by 2007 and remained generally stable thereafter (Table 3). However, on a per capita basis, the estimated number of such trips declined by an annual average of $-0.4 \%$ over the study period. Trips per capita declined by 32.1\% from a peak in 1999 to 2001, remained generally stable in subsequent years and were still 21.0\% below 1999 levels in 2012. The market share of day nature trips as a percent of total day trips made in Australia overall by domestic visitors also declined by an annual average of $-0.6 \%$ over the period (Table 3 ). 
The estimated number of overnight nature trips made in Australia by domestic visitors remained generally stable over the study period, with a low mean annual change of $+0.6 \%$. Although trips declined significantly (non-overlapping standard errors) by 21.4\% from a peak in 1998 to 2001, levels recovered by 2006 and remained generally stable thereafter. The market share of overnight nature trips as a percent of total overnight trips by domestic visitors also increased by an annual average of $+0.5 \%$ (Table 3). However, on a per capita basis, the estimated number of overnight nature trips made in Australia declined by an annual average of $-0.8 \%$ over the study period. Trips per capita declined by 23.6\% from a peak in 1998 to 2001, remained generally stable in subsequent years, and were still 13.9\% below 1998 levels in 2012 (Table 3).

\section{Discussion}

The trends outlined in this paper show that the nature tourism industry has effectively stagnated in Australia overall and declined in the GBMWHA in terms of absolute number of domestic nature trips made during the 15-year period of this study (1998-2012). Although the number of nature trips made by international visitors to Australia has remained effectively stable in absolute terms over time nature tourism's market share of total international visits declined from a peak of $68.0 \%$ in 2005 to 62.0\% in 2012 (Table 2). This decline occurred following rapid growth in international tourism to Australia throughout the 1980s and 1990s (Bushell, Prosser, Faulkner, and Jafari, 2001; Faulkner and Walmsley, 1998), and in a period when nature-based tourism was considered a large and growing segment of the tourism industry worldwide by many tourism researchers (Balmford, 2009; Bell et al., 2007; Buckley, 2003; Nyaupane et al., 2004).

The large majority of nature trips in Australia overall were made by domestic tourists, with broadly equivalent numbers of overnight and day trips, although domestic overnight visitors were twice as likely to include a nature activity in their trips (18.0\%) as day visitors (9.0\%). Although some variability occurred during the study period, overall the numbers of both domestic day and 
overnight nature trips remained broadly stable over the study period (Table 3). These data, in the context of strong Australian population growth of $21.4 \%$ during the period have meant that both day and overnight domestic nature trips have declined in per capita terms and these trends have not been compensated by a small growth $(+2.0 \%)$ in a relatively small international tourism base.

Nature visitation to the GBMWHA declined between 1999 and 2001 for international tourists, and overnight and day domestic trips also declined over the study period although the decline was most marked between 2000 and 2001, and in the latter half of the decade figures tended to stabilise (Table 2) well below the higher earlier levels of the rapid growth phase reported (e.g., Bushell et al., 2001; Faulkner and Walmsley, 1998) of the 1980s and 1990s. There was also a decline in nature tourism’s market share for Australia overall among international tourists and domestic day trips (Table 2, 3). As noted, domestic day and overnight trips declined on a per capita basis for Australia total over the study period (Table 3).

Trends in absolute numbers of domestic nature trips and trips per capita are both important: the former in terms of economic benefit generated; the latter potentially reflecting declining interest in the natural resource. The declining per capita nature visitation revealed here supports similar findings in public natural areas in the U.S. (Balmford et al., 2009; Pergams and Zaradic, 2008; Warnick et al., 2009) and Japan (Balmford et al., 2009; Pergams and Zaradic, 2008). Balmford et al. (2009) also found that, overall, there has been a declining per capita visitation among 15 Australian protected areas (13 in Tasmania, and Uluru and Kakadu in the Northern Territory). However, as previously noted, globally, per capita visit declines have not been universal, even among developed countries (Balmford et al., 2009; Pergams and Zaradic, 2008; Zaradic, 2008).

Reasons for the declines observed have been argued by some authors as evidence for a 'fundamental and pervasive shift away from nature-based recreation' (Pergams and Zaradic, 2008, p. 2295), associated with growth in 'videophilia'; the love of sedentary activities involving electronic media (Pergams and Zaradic, 2006) in place of 'biophilia'; the appreciation of nature (Wilson, 1984). 
Such activities draw the user into a more sedentary lifestyle and, together with a more closeted (structured and supervised) childhood, discourage interaction with nature (Fjørtoft, 2001; White and Stoecklin, 1998). However, such change in behaviours does not necessarily explain the decline in nature trips to Australia, and changes in the GBMWHA that we observed occurred early the 2000s after two decades of rapid increase in visitation. While the advent of videophilia is very likely to have exacerbated the situation, some researchers (e.g., Louv, 2005; Osborne, Simon, and Collins, 2003; Weigl, 2009; Zaradic and Pergams 2007) have suggested that changes in the education system has resulted in the 'increasing abandonment' of the natural world in education over the past 40 years (Weigl, 2009). In isolation, none of these changes (increased interest in videophilia, increasingly closeted play, or decline in nature teaching in the education system) correlate with the pattern of change in nature visitation that has occurred in Australia in recent decades. Broadly, this has included a significant rise in nature tourism over the 1980s and 1990s followed by a decline in the early 2000s, and subsequent stabilisation in terms of absolute numbers beyond the mid-2000s (although not in per capita terms as revealed here).

Some authors (e.g., Balmford et al., 2009; Buckley, 1999, 2009) have hypothesised that longestablished protected areas in richer countries (e.g., U.S.) may have become overcrowded and visitors displaced to other, unmonitored sites and thus, in reality, overall global nature visitation may be stable or even increasing. The local management of natural areas within the GBMWHA (National Parks and Wildlife Service) has posited this as a reason for the apparent decline in recent years of 'canyoning' adventure recreation in the most popular canyons of the GBMWHA (Hardiman and Burgin, 2010b). From small beginnings that commenced with the first traverse of a canyon in 1962 (Jamieson, 2001), by the 1990s anecdotal evidence indicated that canyoning was increasing in popularity, and was assumed to be sufficiently popular to be environmentally problematic. This is reflected in plans of management for the natural areas of the GBMWHA (Hardiman and Burgin (2011a). For example, in the 1988 Plan of Management there was scant comment on adventure recreation including canyoning (NPWS, 1988). A decade later, 'major sections’ of the 1998 and 2001 
plans of management were devoted to consideration of the impacts of adventure recreation including canyoning, and policies proposed to manage the environmental impacts of such activities (Hardiman and Burgin, 2011a; NPWS, 1998a, 2001).

As a segment of a larger project on the impacts of canyoners in the GBMWHA (e.g., Hardiman and Burgin, 2010a, b, c, 2011a, b, c), and in collaboration with park management, track head sampling was carried out in 2000 to 2002, and in 2010. The surveys showed that there was a decline in canyoning of 30.5\% between 2000 and 2002, with only a subsequent small increase (4.8\%) in the sport between 2002 and 2010 (Hardiman and Burgin, 20011a). This substantial decline occurred despite a growing popularity of sport tourism including adventure tourism that incorporated attractions, tours, and adventure (Ritchie and Adair, 2016). However, within the GBMWHA no specific identifiable reasons for the decline in canyoning were identified beyond 'the broader pattern of decline in visitation to the area’ (Hardiman and Burgin, 2011a, p. 1330).

Since international visitors represented approximately only $10 \%$ of canyoners (Hardiman and Burgin, 2011a) (corresponding to the same overall percentage of international nature visitors revealed here in the NVS and IVS data), variation in the numbers of canyoners would best be reflected in changes in domestic nature tourism. Comparison of the years sampled for canyoners (Hardiman and Burgin, 2011a), and nature (including per capita) trips to the GBMWHA outlined above, reveal that the downward trend for canyoning was more dramatic than nature trips to the GBMWHA more generally, although the pattern of decline in both databases showed broadly similar trends. Unlike nature trips to the GBMWHA, however, canyoning is unique to the GBMWHA (Hardiman and Burgin, 2010b, 2011a), due to the unique geological formations that allowed for the formation of slot canyons, and thus unlike a decline in nature visits more generally that may result in a shift to a different venue, decline in canyoning represents a real decline in the sport.

A review of visitation to other major natural areas in the Sydney Region did not reveal a pattern that could be attributed to a change in destination preference among nature visitors. Royal National Park (Royal) on the southern outskirts of Sydney, the oldest National Park in Australia 
(Moriarty, 2004), had similar numbers of visitors overall to the GBMWHA between 2008 and 2012 (GBMWHA - 10.38 million; Royal - 10.15 million). A review of the five parks with significant visitation in the Sydney Basin, revealed that three showed a downward trend in visitation in 2008, 2010 and 2012 (bi-annual data were presented) including GBMWHA (Royal numbers increased in 2012 to above the GBMWHA), however, there was no clear pattern to show that visitors were switching natural areas (Roy Morgan Research Ltd, 2015).

One possible reason for fluctuation in visitor numbers (or even change in natural area preference) is that fire is an integral component of Australia's natural environment (Whelan, Kanowski, Gill, and Andersen, 2006), and the GBMWHA is one of the most fire prone areas in the World (NPWS, 1998b). In the current study period, major fires occurred in the Region in 1997-1998, 2001-2002, 2003-2003, and 2006-2007; however, any interpretation of visitor data for the period is complicated by the lack of data for visitors in 1997 and for international visitors also in 1998 (19971998 fires), the Olympics Games in Sydney in 2000, the year immediately preceding several years of severe fires (2001-2003), and the peak of the Global Financial Crisis (2008) followed fires in 20062007. The pattern of visitation was broadly similar between visitations to Australia overall, and for visitation to the Blue Mountains. No clear pattern that could be attributed only to fire emerged.

It may have been predicted that the Global Financial Crisis of 2008 would have reduced international nature travel with fewer inbound tourists and more domestic nature tourists holidaying within Australia. However, despite the negative impact on tourism that occurred in some other areas of the world (Ruhanen, MacLennan, and Moyle, 2013; Sheldon and Dwyer, 2010) during the Crisis in 2008, inbound international nature trips made in Australia, and percent market share, remained essentially stable, as did the number of nature trips to the GBMWHA.

Another factor that has been suggested for a decline in tourism in a specific country is that nature visitors in affluent countries are becoming wealthier and shunning domestic natural areas, choosing instead to visit natural areas in overseas locations which may be perceived to offer better value and/or more exotic experiences (Balmford et al., 2009; Prosser and Carter, 1994). While data 
were unavailable for Australian outward bound 'nature tourism' specifically, departures from Australia to overseas destinations for 'holidays' in general increased from 2,098 to 4,118 million during the period of the study (TRA, 2015d), a 49.1\% increase while domestic nature visits remained relatively stable (Table 3). Comparison between the increasing numbers of Australians travelling overseas for holidays and the increase in the Gross National Income Purchasing Power Parity over the study period also indicated that there was a strong significant positive relationship between level of disposable income and overseas holidays $\left(\mathrm{r}^{2}=0.893, \mathrm{p}=0.0013\right)$. The strengthening of the Australian dollar, reflected in the increasingly strong Purchasing Power Parity for Australians (Table 3), made overseas holidays relatively cheaper for Australians during the study period while simultaneously increasing the cost of inbound travel for overseas visitors. The growth in overseas holiday travel by Australians may thus partly explain the observed decline in number of domestic nature trips per capita despite a growing population. This conclusion was supported by the research of Allen and Yap (2009) who used a time-series from 1999-2007 from seven Australian states. They found that tourism demand was 'strongly responsive' to Australian economic conditions and that domestic tourism was less attractive in times of stronger economic conditions.

Apart from the strong dollar, others factors that may have encouraged a growth in outbound international tourism during the study included an increase in aviation capacity supply to and from Australia, coupled with fierce competition, the latter spurred by the growth of new low-cost, regional carriers such as AirAsia and Tiger Airways. For example, during 2010, airline capacity to Indonesia ‘expanded almost continuously’ (TRA, 2011, p. iv), and outbound trips to Indonesia rose by 35\% making that country Australia's second largest outbound market behind New Zealand (TRA, 2011). Previous researchers (e.g., Buckley, 2009; Moyle and Weiler, 2016; Weiler, Moore, and Moyle, 2013) have identified that visitation provides the 'political capital' for parks to survive. For example, Moyle and Weiler (2016) found that those who had visited a protected area within the past 12 months held such areas in higher perceived value than non-visitors. Strategies to encourage visitation should, therefore, be a major target for land managers. This will require ensuring a 
diversity of experiences (Weiler et al. (2013), and because children may foster environmentally responsible behaviour in adults (Chawla, 1998; Wells and Likies, 2006; Zaradic and Pergams, 2007), a particular focus on encouraging them to appreciate parks enhance visitation as children and beyond.

\section{Conclusions}

The results of this 15-year study showed declining per capita nature trips to the GBMWHA, despite World Heritage listing in 2000 and the Olympic Games in Sydney in the same year, together with a decline in per capita nature visitation for Australia overall. These data add to the research of Balmford et al. (2009) who found that per capita nature tourism was declining in 15 other Australian protected areas (13 in Tasmania), and Uluru and Kakadu in the Northern Territory. Such findings of declining relative interest in nature tourism are of specific concern to the GBMWHA and Australia more generally. Such trends in nature tourism challenge common but rarely quantified claims that nature tourism is growing globally (Balmford, 2009; Bell et al., 2007; Buckley, 2003; Nyaupane et al., 2004). Evidence to the contrary would potentially be of significance to Australia economically. This is because research undertaken by Tourism Australia consistently shows that 'nature' motivates people to travel to Australia more than any other concept, and Australian tourism relies heavily on this natural capital. For example, in May 2010, following intensive market research, Tourism Australia launched a new branding campaign 'There's nothing like Australia'. This campaign, which is ongoing (Tourism Australia 2013-2016), targets both domestic and international visitors, and has Australia’s unique wildlife and scenery at its core (Tourism Australia, 2013a, b).

Visitation provides the 'political capital' for parks to survive. However, based on current data it would appear that without broadening its base this major Australian industry, focused as it is largely on nature, is susceptible to continued decline. A further issue is that for countries in which per capita nature tourism is declining, there are important implications for biodiversity conservation. Policymakers and land management agencies may in future face a fundamentally different challenge to that of the past. The old problem of how to avoid 'loving our` parks to death' and seeing protected 
areas as some form of 'fortress' within which to protect biodiversity against waves of tourists ('fortress conservation'- cf. Bell, 2011; Büscher, 2016) may no longer be the key issue in their management. Instead, the emerging issue may be 'how can we encourage more people to visit our natural areas and/or more frequently?’ to foster awareness and understanding of their values and generate ongoing support for their funding. Strategies to encourage visitation should be a major target for land managers. If unsuccessful, apathy may prove a worse threat to conservation than overuse. Such an outcome would have significant implications for regional economic development interests, conservation management in Australia’s critical ecological areas and, potentially, long term public health and conservation advocacy consequences in Australian society, and therefore, a new management philosophy, focused on ecologically sustainable tourism may be required. Since children foster environmentally responsible behaviour in adults, they should be part of the focus for developing diverse experiences that encourage park visitation.

\section{References}

ABS (2015). 3218.0 Regional population growth, Australia, 2011-2012. Australian Bureau of Statistics, Canberra. http://www.abs.gov.au/ausstats/abs@.nsf/mf/3218.0. Allen, D.E., \& Yap, G. (2009). Modelling Australian domestic tourism demand: A panel data approach. School of Accounting, Finance and Economics \& FEMARC Working Paper Series, Edith Cowan University, October 2009, Working Paper 0910.

Armstrong, E.K., \& Kern, C.L. (2011). Demarketing manages visitor demand in the Blue Mountains National Park. Journal of Ecotourism, 10, 21-37.

Australia.com (2016). Blue Mountains. http://www.australia.com/en-in/places/blue-mountains.html

Balmford A, Beresford J, Green J, Naidoo R, Walpole M., \& Manica, A. (2009). A global perspective on trends in nature-based tourism. PLoS Biology, 7(6), e1000144.

Baum, S. (1997). Sydney, Australia: a global city? Testing the social polarisation thesis. Urban Studies, 34, 1881-1902. 
Bell, J.P.W. (2011). A national parkless Northern Island: the tourism resource paradox and the implications for sustainability. WIT Transactions on Ecology and the Environment, 150, 491504.

Bell, S. Tyrväinen, L. Sievänen, T. Pröbstl, U., \& Simpson, M. (2007). Outdoor recreation and nature tourism: a European perspective. Living Reviews in Landscape Research 1(2007) 2 [Online article] http://creativecommons.org/licenses/by-nc-nd/2.0/de/.

Buckley, R. (1999). An ecological perspective on carrying capacity. Annals of Tourism Research, 26, 705-708.

Buckley, R. (2003). The practice and politics of tourism and land management. In: R. Buckley, C. Pickering, \& D. B. Weaver (Eds.) Nature-based tourism, environment and land management. Wallingford: CABI Publishing.

Buckley, R. (2009). Parks and Tourism. PloS Biology, 7(6), e1000143.

Büscher, B. (2016). Reassessing fortress conservation? New media and the politics of distinction in Kruger National Park. Annals of the American Association of Geographers, 106, 114-129.

Bushell, R., \& Eagles, P.F.J. (Eds.) (2007). Tourism and protected areas: benefits beyond boundaries. Wallingford: CABI.

Bushell, R., Prosser, G.M., Faulkner, H.W., \& Jafari, J. (2001). Tourism Research in Australia. Journal of Travel Research, 39, 323-326.

Chawla, L. (1998). Significant life experiences revisited: A review of research on sources of environmental sensitivity. Environmental Education Research, 4, 369-382.

DECC (2009). Greater Blue Mountains World Heritage Area Strategic Plan. Sydney: Department of Environment and Climate Change.

Destination NSW (2016). Blue Mountains highlights. http://www.sydney.com/destinations/bluemountains. 
Eagles, P.F.J. (2002). Trends in park tourism: economics, finance and management. Journal of Sustainable Tourism, 10, 132-153.

Faulkner, H.W., \& Walmsley, D.J. (1998). Globalisation and the pattern of inbound tourism in Australia. Australian Geographer, 29, 91-106.

Fjørtoft, I. (2001). The natural environment as a playground for children: the impact of outdoor play activities in pre-primary school children. Early Childhood Education Journal, 29, 111-117

Gössling, S. (1999). Ecotourism: a means to safeguard biodiversity and ecosystem functions? Ecological Economics, 29, 303-320.

Hardiman, N., \& Burgin, S. (2010a). Visitor impacts and canyon management in the Blue Mountains, Australia: canyoners’ perspectives and wilderness management. Managing Leisure, 15, 264278.

Hardiman, N., \& Burgin, S. (2010b). Adventure recreation in Australia: a case study that investigated the profile of recreational canyoners, their impact attributes, and response to potential management options. Journal of Ecotourism, 9, 36-44. Hardiman, N., \& Burgin, S. (2010c). The efficacy of the freshwater crayfish Euasiacus spinifer as an environmental indicator of the impacts of canyoners in the Greater Blue Mountains World Heritage Area, Australia. Journal of Crustacean Biology, 30, 771-778.

Hardiman, N., \& Burgin, S. (2011a). Canyoning adventure recreation in the Blue Mountains World Heritage Area (Australia): the canyoners and canyoning trends over the last decade. Tourism Management, 32, 1324-1331.

Hardiman, N., \& Burgin, S. (2011b). Effects of trampling on in-stream macroinvertebrate communities from canyoning activity in the Greater Blue Mountains World Heritage Area. Wetlands Ecology and Management 19, 61-71.

Hardiman, N., \& Burgin, S. (2011c). Comparison of steam macroinvertebrate assemblages in canyon ecosystems of the Blue Mountains (Australia) with and without recreational traffic. Australian Zoologist, 35, 757-769. 
Hardiman, N., \& Burgin, S. (2013). World Heritage Area listing of the Greater Blue Mountains - did it make a difference to visitation? Tourism Management Perspectives, 6, 63-64.

Jamieson. R. (2001). Canyons near Sydney (4 ${ }^{\text {th }}$ Edition). Kurrajong Heights, Rick Jamieson.

Kareithi, S. (2003). Coping with declining tourism, examples from communities in Kenya. PPT Working Paper No. 13, http://hdl.handle.net/123456789/440

Kiss, A. (2004). Is community-based ecotourism a good use of biodiversity conservation funds? Trends in Ecology and Evolution, 19, 232-237.

Kruger, O. (2005). The role of ecotourism in conservation: panacea or Pandora’s Box? Biodiversity and Conservation, 14, 579-600.

Louv, R. (2005). Animal, vegetable, miracle. Harper Collins Publisher, New York. In:

Moriarty, A.J. (2004). Wild deer herds in Australia’s urban fringe: issues, management and politics. In: D. Lunney, \& S. Burgin (Eds.). Urban wildife: More than meets the eye. Mosman: Royal Zoological Society of New South Wales, pp. 179-185.

Moyle, B.D., \& Weiler, B. (2016). Revisiting the importance of visitation: public perceptions of park benefits. Tourism and Hospitality Research (early-on-line).

Naidoo, R., \& Adamowicz, W.L. (2005). Biodiversity and nature-based tourism at forest reserves in Uganda. Environment and Development Economics, 10, 159-178.

Naidoo, R., Balmford, A., Ferraro, P.J., Polasky, S., Ricketts, T.H., \& Rouget, M. (2006). Integrating economic costs into economic planning. Trends in Ecology and Evolution, 21, 681-687.

Naughton-Treves, L., Holland, M.B., \& Brandon, K. (2005). The role of protected areas in conserving biodiversity and sustaining local livelihoods. Annual Review of Environmental Resources, 30, 219-252.

NPWS (1988). Blue Mountains National Park: Draft Plan of Management. Hurstville: National Parks of New South Wales.

NPWS (1998a). Blue Mountains National Park: Draft Plan of Management. Hurstville: National Parks of New South Wales. 
NPWS (1998b). World Heritage Nomination: Nomination of the Greater Blue Mountains Area for Inscription on the World Heritage List by the Government of Australia 1998. Hurstville: New South Wales National Parks, \& Canberra: Wildlife Service [Hurstville] in Association with Environment Australia.

NPWS (2001). Blue Mountains National Park Plan of Management. Hurstville: National Parks of New South Wales.

Nyaupane, G.P., Morais, D.B., \& Graefe, A.R. (2004). Nature tourism constraints: a cross-activity comparison. Annals of Tourism Research, 31, 540-555.

Osborne, J., Simon, S., \& Collins, S. (2003). Attitudes towards science: a review of the literature and its implication. International Journal of Science, 25, 1049-1079.

Pergams, O.R.W., \& Zaradic, P.A. (2006). Is love of nature in the US becoming love of electronic media? 16-year downtrend in national park visits explained by watching movies, playing video games, internet use, and oil prices. Journal of Environmental Management, 80, 387393.

Pergams, O.R.W., \& Zaradic, P.A. (2007). Videophila: implications for childhood development and conservation. Journal of Developmental Processes, 2, 130-144.

Pergams, O.R.W., \& Zaradic, P.A. (2008). Evidence for a fundamental and pervasive shift away from nature-based recreation. Proceedings of the National Academy of Sciences of the United States of America, 105, 2295-2300.

Ritchie, B., \& Adair, D. (2016). The growing recognition of sport tourism. Current Issues in Tourism, 5, 1-6.

Roy Morgan Research Ltd (2015). Annual visits to PWG management parks in New South Wales. Brisbane: Roy Morgan Research Ltd.

Prosser, T., \& Carter, E. (1994). Societal change and growth in alternative tourism. In: E. Cater, \& G. Lowman (Eds). Ecotourism: A Sustainable Option? Wallingford: CABI Publishing. pp. 1938. 
Ruhanen, L.M., Mclennan, C.-L.J., \& Moye, B.D. (2013). Strategic issues in the Australian tourism industry: a 10-year analysis of national strategies and plans. Asian Pacific Journal of Tourism Research, 18, 220-240.

Shaw, G., \& Williams, A. [Eds.] (1997). The rise and fall of British coastal resorts: cultural and economic perspectives. London: Pinter.

Sheldon, P., \& Dwyer, L. (2010). The global financial crisis and tourism: perspectives of the academy. Journal of Travel Research, 49, 3-4.

Short, J.R., Breitbach, C., Buckman, S., \& Essx, J. (2000). From world cities to gateway cities: extending the boundaries of globalization theory. City, 4, 317-340.

Silori, C.S. (200). Socio-economic and ecological consequences of the ban on adventure tourism in Nanda Devi Biosphere Reserve, Western Himalaya. Biodiversity and Conservation, 13, 22372252.

SWRN (1996-2016). World heritage. Strailia Web’s Regional Network. http://www.bluemts.com.au/info/thingstodo/

The World Bank (2013). GNI, PPP (current international \$). The World Bank. http://data.worldbank.org/indicator/NY.GNP.MKTP.PP.CD.

Tisdell, C. (2010). World Heritage Listing of Australian natural sites: Effects on tourism, economic value and conservation. Working Paper No. 172. October 2010. Working papers on Economics, Ecology and the Environment. St Lucia: University of Queensland.

Tourism Australia (2013a). Campaigns: There’s nothing like Australia. http://www.tourism.australia.com/en-au/marketing/campaigns_Nothing-Like-Australia.aspx. Tourism Australia (2013b). There’s nothing like Australia: campaign prospectus, May 2012. http://www.tourism.australia.com/en-au/downloads/TNLA_Campaign_ProspectusDomestic_2012_13.pdf.

Tourism Australia (2013-2015). There’s nothing like Australia. Tourism Australia Corporate Website. 
TRA (2009). Snapshots 2009. Nature Tourism Australia, Department of Resources, Energy and

Tourism, Australian Government.

https://www.google.com.au/\#q=TRA+2009+definition+\%27nature+tourism\%27

TRA (2011). What is driving Australians’ travel choices? Canberra: Tourism Research Australia.

http://www.tourism.australia.com/campaigns/TNLA.aspx

TRA (2012). Tourism's Contribution to the Australian Economy, 1997-98 to 2010-11. Canberra:

Tourism Research Australia.

TRA (2013). National Visitor Survey and International Visitor Survey. Canberra: Tourism Research Australia.TRA (2014). Publishing guidelines and tips for using TRA data. Tourism Research Australia, Australian Government.

https://www.google.com.au/\#q=\%27Published+guidelines+and+tips+for+using+TRA+data\% 27

TRA (2015a). National Visitor Survey Methodology. Tourism Research Australia, Australian Government - Austrade. http://www.tra.gov.au/aboutus/national-visitor-survey.html TRA (2015b). International Visitor Survey. http://www.tra.gov.au/aboutus/international-visitorsurvey.html

TRA (2015c). Fact sheet: 2014 updates to the IVS/NVS. Tourism Research Australia. http://tra.gov.au/Fact-sheet-2014-Updates-to-the-IVS-NVS.html

TRA (2015d). Outbound tourism statistics: National Visitor Survey Results. Tourism Research Australia, Australian Government - Austrade. http://www.tra.gov.au/research/Australianstravelling-overseas.html

TRA (undated). Blue Mountains Region. Tourism profiles. Tourism Research Australia, Australian Government - Austrade. http://tra.gov.au/Tourism_Region_Profiles/Region_profiles/index.html\# UNESCO (1992-2011). World Heritage. United Nations Educational, Scientific and Cultural Organization. http://whc.unesco.org/en/list. 
UNWTO (2012). World Tourism Barometer, May 2012. United Nations World Tourism

Organization. http://mkt.unwto.org/barometer.

Warnick, R.B., Stevens, T., Schuett, M.A., Kuentzel, W., \& More, T.A. (2009). Changes in national park visitation (2000-2008) and interest in outdoor activities (1993-2008). In: C.E. Watts, E.Jr. Fisher, \& C. LeBlanc (Eds.). Proceedings of the 2009 Northeastern Recreation Research Symposium. Gen. Tech. Rep. NRS-P-66. Philadelphia: U.S. Department of Agriculture, Forest Service, Northern Research Station, pp. 204-213.

Weigl, P.D. (2009). The natural history conundrum revisited: mammalogy beings at home. Journal of Mammalogy, 90, 265-269.

Weiler, B., Moore, S. A., \& Moyle, B. D. (2013). Building and sustaining support for national parks in the $21^{\text {st }}$ century: why and how to save the national park experience from extinction. Journal of Park and Recreation Administration, 31, 115-131.

Wells, N.M., \& Lekies, K. S. (2006). Nature and the life course: pathways from childhood nature experiences to adult environmentalism. Child Youth Environment, 16, 1-24. Whelan, R., Kanowski, K., Gill, M., \& Andersen, A. (2006). Living in a Land of Fire. Prepared for the 2006 Australia State of the Environment Committee, Canberra: Department of Environment and Heritage. http://www.deh.gov.au/soe/2006/integrative/fire/index.html>.

White, R., \& Stoecklin, V. (1998). Children’s outdoor play and learning enviornments: returning to nature. Early Childhood News. www.whitehutchinson.com/children/articles/outdoor.shtml Wilkie, D.S., \& Carpenter, J.F. (1999). Can nature tourism help finance protected areas in the Congo Basin? Oryx, 3, 333-339.

Wilson, E.O. (1984). Biophilia. Cambridge MA: Harvard University Press.

Zaradic, P.A., \& Pergams, O.R.W. (2007). Videophilia: implications for childhood development and conservation. The Journal of Developmental Processes, 2, 130-144.

Zaradic, P.A. (2008). Confronting videophilia. Scientific American, 18, 24. 
Table 1: Greater Blue Mountains World Heritage Area nature visitation compared to Greater Sydney population 1998-2012², 3

\begin{tabular}{|c|c|c|c|c|c|c|c|c|c|c|c|c|c|c|c|c|}
\hline & 1998 & 1999 & 2000 & 2001 & 2002 & 2003 & 2004 & 2005 & 2006 & 2007 & 2008 & 2009 & 2010 & 2011 & 2012 & Change $^{4}$ \\
\hline International & $\mathrm{na}^{5}$ & 78 & 76 & 58 & 55 & 53 & 52 & 65 & 49 & 59 & 66 & 65 & 70 & 61 & 66 & $-0.2 \%$ \\
\hline Domestic day & 1291 & 1024 & 1063 & 729 & 642 & 675 & na & 681 & 566 & 676 & 590 & 726 & 811 & 769 & 817 & $-2.2 \%$ \\
\hline $\begin{array}{l}\text { Domestic day/ capita } \\
\text { Sydney }\end{array}$ & 0.3 & 0.3 & 0.3 & 0.2 & 0.2 & 0.2 & na & 0.2 & 0.1 & 0.2 & 0.1 & 0.2 & 0.2 & 0.2 & na & $-2.8 \%$ \\
\hline Domestic overnight & 514 & 450 & 344 & 316 & 364 & 264 & 203 & 279 & 302 & 293 & 310 & 306 & 284 & 291 & 331 & $-1.7 \%$ \\
\hline $\begin{array}{l}\text { Domestic overnight/ } \\
\text { capita Sydney }\end{array}$ & 0.1 & 0.1 & 0.1 & 0.1 & 0.1 & 0.1 & 0.1 & 0.1 & 0.1 & 0.1 & 0.1 & 0.1 & 0.1 & 0.1 & na & $-4.2 \%$ \\
\hline Greater Sydney & 3970 & 4020 & 4069 & 4128 & 4163 & 4191 & 4214 & 4245 & 4282 & 4340 & 4411 & 4487 & 4550 & 4606 & na & $+1.1 \%$ \\
\hline
\end{tabular}

${ }^{1}$ International visits not specified by purpose in Regional statistics; ${ }^{2}$ Source: ABS (2013), TRA (2013); ${ }^{3}$ Figures x $1000 ;{ }^{4}$ Change $=$ mean average change; ${ }^{5}$ na $=$ not available 
Table 2: Number of trips made to the Blue Mountains compared to Greater Sydney population (1998-2012) ${ }^{1-5}$

$1998 \quad 19992000 \quad 20012002 \quad 2003 \quad 2004 \quad 2005 \quad 2006 \quad 2007 \quad 2008 \quad 20092010 \quad 2011 \quad 2012 \quad$ Chge $^{1}$

\begin{tabular}{|c|c|c|c|c|c|c|c|c|c|c|c|c|c|c|c|c|}
\hline \multirow{3}{*}{$\begin{array}{l}\text { International visitor } \\
\text { trips } \\
\text { Holiday/pleasure } \\
\text { (millions) } \\
+\mathrm{SE} /-\mathrm{SE}^{2}\end{array}$} & \multirow{3}{*}{ na ${ }^{3}$} & & & & & & & & & & & & & & & \multirow{3}{*}{$-0.2 \%$} \\
\hline & & 78 & 76 & 58 & 55 & 53 & 52 & 65 & 49 & 59 & 66 & 65 & 70 & 61 & 66 & \\
\hline & & $\begin{array}{l}67- \\
89\end{array}$ & $\begin{array}{l}66- \\
86\end{array}$ & $\begin{array}{c}50- \\
66\end{array}$ & $\begin{array}{l}47- \\
63\end{array}$ & $\begin{array}{l}46- \\
60\end{array}$ & $\begin{array}{c}45- \\
59\end{array}$ & $\begin{array}{c}56- \\
74\end{array}$ & $\begin{array}{c}39- \\
59\end{array}$ & $\begin{array}{l}51- \\
67\end{array}$ & $\begin{array}{l}57- \\
75\end{array}$ & $\begin{array}{l}56- \\
74\end{array}$ & $\begin{array}{l}60- \\
80\end{array}$ & $\begin{array}{c}53- \\
69\end{array}$ & $\begin{array}{l}57- \\
75\end{array}$ & \\
\hline \multicolumn{17}{|l|}{ Domestic visitors } \\
\hline $\begin{array}{l}\text { Day nature trips } \\
\text { (millions) }\end{array}$ & 1291 & 1024 & 1063 & 729 & 642 & 675 & na & 681 & 566 & 676 & 590 & 726 & 811 & 769 & 817 & $-2.2 \%$ \\
\hline$+\mathrm{SE} /-\mathrm{SE}$ & $\begin{array}{l}1044- \\
1537\end{array}$ & $\begin{array}{l}828- \\
1220\end{array}$ & $\begin{array}{l}860- \\
1266\end{array}$ & $\begin{array}{c}533- \\
925\end{array}$ & $\begin{array}{l}469- \\
815\end{array}$ & $\begin{array}{l}493- \\
857\end{array}$ & & $\begin{array}{l}498- \\
864\end{array}$ & $\begin{array}{l}414- \\
718\end{array}$ & $\begin{array}{l}494- \\
858\end{array}$ & $\begin{array}{c}431- \\
749\end{array}$ & $\begin{array}{c}531- \\
921\end{array}$ & $\begin{array}{l}593- \\
1029\end{array}$ & $\begin{array}{c}562- \\
976\end{array}$ & $\begin{array}{l}597- \\
1037\end{array}$ & \\
\hline Day nature trips/capita & 0.33 & 0.25 & 0.26 & 0.18 & 0.15 & 0.16 & na & 0.16 & 0.13 & 0.16 & 0.13 & 0.16 & 0.18 & 0.17 & 0.17 & $-3.5 \%$ \\
\hline $\begin{array}{l}\text { Overnight nature trips } \\
\text { (millions) }\end{array}$ & 514 & 450 & 344 & 316 & 364 & 264 & 203 & 279 & 302 & 293 & 310 & 306 & 284 & 291 & 331 & $-1.7 \%$ \\
\hline$+\mathrm{SE} /-\mathrm{SE}$ & $\begin{array}{l}435- \\
593\end{array}$ & $\begin{array}{c}362- \\
538\end{array}$ & $\begin{array}{l}277- \\
411\end{array}$ & $\begin{array}{l}254- \\
378\end{array}$ & $\begin{array}{c}293- \\
435\end{array}$ & $\begin{array}{l}201- \\
327\end{array}$ & $\begin{array}{l}154- \\
252\end{array}$ & $\begin{array}{l}212- \\
346\end{array}$ & $\begin{array}{l}243- \\
361\end{array}$ & $\begin{array}{l}223- \\
363\end{array}$ & $\begin{array}{l}249- \\
371\end{array}$ & $\begin{array}{l}246- \\
366\end{array}$ & $\begin{array}{l}216- \\
352\end{array}$ & $\begin{array}{l}221- \\
361\end{array}$ & $\begin{array}{l}266- \\
396\end{array}$ & \\
\hline $\begin{array}{l}\text { Overnight nature } \\
\text { trips/capita }\end{array}$ & 0.13 & 0.11 & 0.08 & 0.08 & 0.09 & 0.06 & 0.05 & 0.07 & 0.07 & 0.07 & 0.07 & 0.07 & 0.06 & 0.06 & 0.07 & $-2.7 \%$ \\
\hline Sydney Population ${ }^{4}$ & 3970 & 4020 & 4069 & 4128 & 4163 & 4191 & 4214 & 4245 & 4282 & 4340 & 4411 & 4487 & 4550 & 4606 & 4670 & $1.2 \%$ \\
\hline
\end{tabular}

${ }^{1}$ Chge = Mean annual change; ${ }^{2}+/$-SE $=$ relevant standard error rate applied (see Table 1$) ;{ }^{3}$ na $=$ not available; ${ }^{4}$ Sydney population $=$ Greater Sydney Region population. ${ }^{5}$ Source: TRA (2013), TRA (undated), ABS (2013) 
Table 3: Number of nature trips made in Australia, and percent market share compared to Australian population and Gross National Income Purchasing Power Parity (GNI PPP), 1998-2012

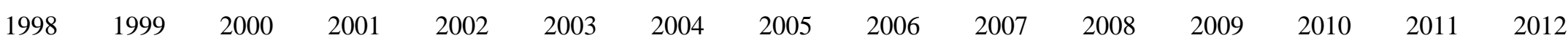

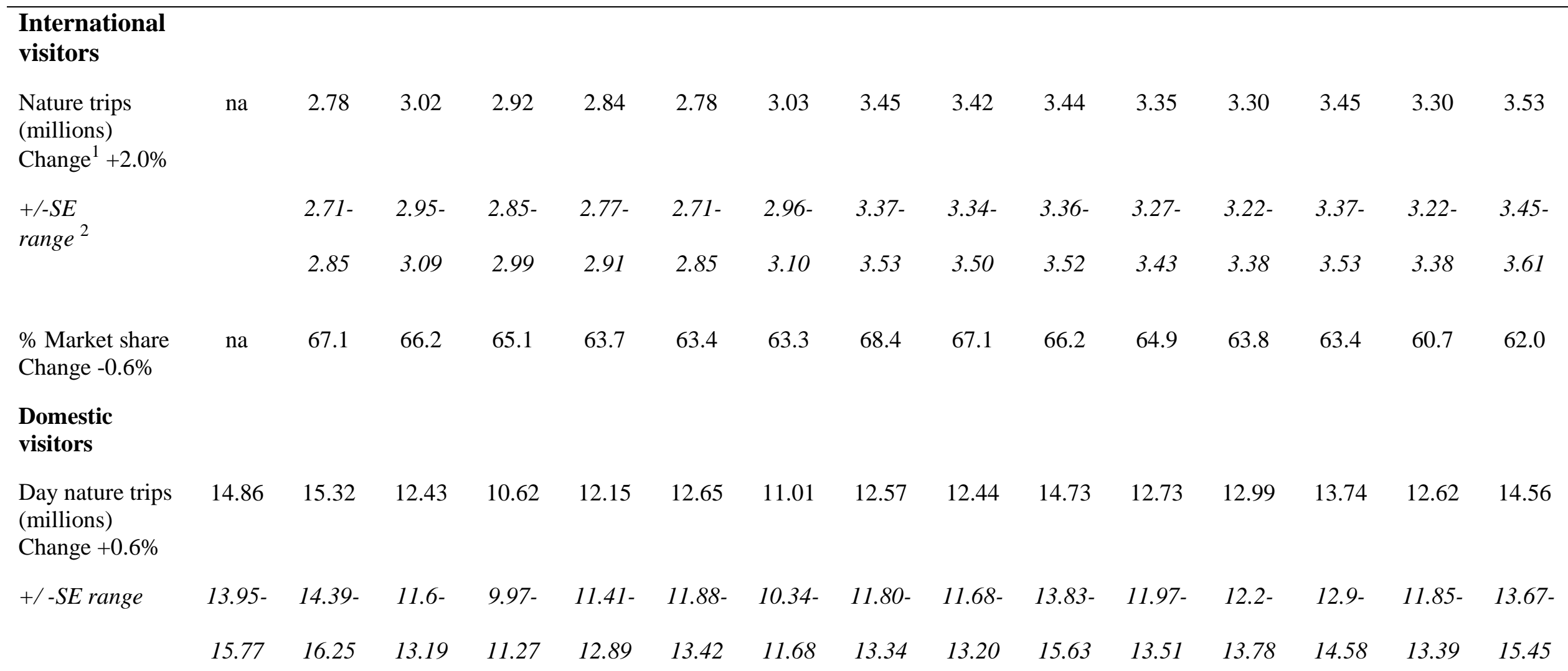




\begin{tabular}{|c|c|c|c|c|c|c|c|c|c|c|c|c|c|c|c|}
\hline $\begin{array}{l}\text { \% Market share } \\
\text { Change }-0.6 \%\end{array}$ & 9.7 & 9.0 & 7.7 & 7.3 & 8.5 & 9.1 & 8.5 & 9.7 & 9.3 & 9.9 & 9.2 & 8.8 & 8.8 & 7.8 & 8.4 \\
\hline $\begin{array}{l}\text { Day nature } \\
\text { trips/capita } \\
\text { Change }-0.4 \%\end{array}$ & 0.79 & 0.81 & 0.65 & 0.55 & 0.62 & 0.64 & 0.55 & 0.62 & 0.60 & 0.70 & 0.59 & 0.60 & 0.62 & 0.57 & 0.64 \\
\hline $\begin{array}{l}\text { Overnight } \\
\text { nature trips } \\
\text { (millions) } \\
\text { Change }+0.6 \%\end{array}$ & 13.52 & 12.13 & 11.16 & 10.62 & 11.26 & 12.44 & 12.51 & 12.15 & 13.05 & 14.88 & 13.18 & 12.66 & 12.96 & 13.05 & 14.11 \\
\hline$+/-S E$ range & 13.05- & 11.71- & 10.77- & $10.25-$ & 10.87- & $12.00-$ & 12.07- & 11.72- & $12.59-$ & 14.36- & 12.72- & 12.22- & 12.51- & 12.59- & 13.62- \\
\hline & 13.99 & 12.55 & 11.55 & 10.99 & 11.65 & 12.88 & 12.95 & 12.58 & 13.51 & 15.40 & 13.64 & 13.10 & 13.41 & 13.51 & 14.60 \\
\hline $\begin{array}{l}\% \text { Market share } \\
\text { Change }+0.5 \%\end{array}$ & 18.3 & 16.6 & 15.1 & 14.2 & 14.9 & 16.9 & 16.8 & 17.4 & 17.7 & 20.0 & 18.3 & 18.7 & 18.7 & 18.2 & 18.9 \\
\hline $\begin{array}{l}\text { Overnight } \\
\text { nature } \\
\text { trips/capita } \\
\text { Change -0.8\% }\end{array}$ & 0.72 & 0.64 & 0.58 & 0.55 & 0.57 & 0.63 & 0.62 & 0.60 & 0.63 & 0.71 & 0.62 & 0.58 & 0.59 & 0.59 & 0.62 \\
\hline $\begin{array}{l}\text { Australian } \\
\text { population } \\
\text { (millions) } \\
\text { Change }+1.4 \%\end{array}$ & 18.7 & 18.9 & 19.2 & 19.4 & 19.7 & 19.9 & 20.1 & 20.4 & 20.7 & 21.0 & 21.4 & 21.8 & 22.1 & 22.3 & 22.7 \\
\hline $\begin{array}{l}\text { GNI PPI/capita } \\
\text { Australia }(\$ 000) \\
\text { Change }+4.2 \%\end{array}$ & $\$ 23.5$ & $\$ 24.5$ & $\$ 25.5$ & $\$ 26.6$ & $\$ 28.0$ & $\$ 29.0$ & $\$ 30.4$ & $\$ 31.3$ & $\$ 32.8$ & $\$ 34.6$ & $\$ 35.6$ & $\$ 38.6$ & $\$ 37.5$ & $\$ 40.2$ & $\$ 41.8$ \\
\hline
\end{tabular}

